DOI: https://doi.org/10.32838/2523-4803/70-3-52

UDC 336.717

Tsizhma Oksana

Vasyl Stefanyk Precarpathian National University

ORCID: https://orcid.org/0000-0003-2860-0449

Ціжжа О.А.

викладач,

Прикарпатський національний університет

імені Василя Стефаника

\title{
SAVINGS IN BANKING INSTITUTIONS OF UKRAINE AS A FACTOR OF INCREASING THE EFFICIENCY OF FORMATION OF LABOR POTENTIAL OF THE POPULATION
}

There has been conducted the analysis of the dynamics and structure of deposits of legal entities and deposits of individuals for the period of 2015-2019 in the banking system of Ukraine in terms of types of currencies and terms of paying off in the article. The dynamics of changes in interest rates on deposits of residents which have been attracted by deposit-taking corporations in 2015-2019 to the accounts of non-financial corporations and households has been highlighted. The measures for the development and improvement of deposit operations have been substantiated. The practical significance of the obtained results lies in the scientific substantiation of the ways of further development of deposit operations of banks for the formation of banking resources which contributes to modern approaches to the provision of resources and functioning of the banking system of Ukraine.

Key words: banking institutions; banking resources; deposits of residents; deposits of households; deposits of non-financial corporations; deposit interest.

Formulation of the problem. Money savings are of great importance for households and are one of the important sources of investment into Ukraine's economy. Savings provide a steady increase in labor productivity, household employment, maximum consumption per employee and, finally, optimize welfare of the population. Since in the composition of banking resources significant share comprise deposits of individuals, then it is advisable to analyze the activities of banks in the formation and use of household savings. The very deposits of individuals play a significant role in the formation of banking resources and are the level of confidence of customers in the banking system.

The analysis of the recent researches and publications. To the study of banking practice of attracting savings of households the works of domestic economists were devoted to, in particular Yu. M. Halitseiska [1], T.O. Hurzhyi [2], V.M. Dereza [7], O.V. Dziubliuk [3], T.O. Kizyma [4], V.V. Kovalenko [5], N.M. Kuzma [13], O.M. Kumeiko [7], O.S. Serhieieva [5], I. Motoryna [8], V. Novikova [9], Ye.A. Nosova [10], T.I. Pavliuk [12], V.V. Rosola [13], V.A. Urbanovych [12], Ya. I. Chaikovskyi [15], I. Ya. Chaikovska [15] and others. However, the problems of organizing deposit operations of banks in order to form banking resources as a factor of improving the efficiency of labor potential and their investment into the real economy require further research, especially taking into account the latest realities of the Ukrainian economy.
Setting of the task. The purpose of the article is to analyze the current state and development of the corresponding measures for the development and improvement of deposit operations of banks with households for expanding their lending and investment activities. To achieve this purpose, the solution of the following tasks has been determined: to investigate the dynamics and structure of residents' deposits which are attracted by deposit-taking corporations, by economic sectors and by currency; to analyze the current state of deposit operations of banking institutions of Ukraine; to identify the problems of formation of savings of the population and to propose the main directions of improving management of deposit operations of banking institutions at the present stage of development.

Presentation of the main research material. During 2015-2019, an upward trend in residents' deposits has been observed (Table 1).

During 2015-2019 residents' deposits increased by 354.938 million UAH, or by $49.5 \%$. This indicates to an increase in confidence of residents, both of non-financial corporations and households, in 2015-2019 to the banking system and acceptable proposals of banks to attract funds on deposits of legal entities and deposits of individuals. By sectors of the economy, the share of households in residents' deposits decreased from $57.3 \%$ in 2015 to $55.1 \%$, in 2017, in 2018 it increased to $56.8 \%$, and in 2019 it decreased again to $53.8 \%$ (see Table 1 ). 
Table 1

Residents' deposits attracted by deposit-taking corporations, by sectors of economy

\begin{tabular}{|c|c|c|c|c|c|c|c|}
\hline \multirow{2}{*}{ Period } & \multirow{2}{*}{ Total } & \multicolumn{2}{|c|}{ Non-financial corporations } & \multicolumn{2}{c|}{ Households } & \multicolumn{2}{c|}{ Other residents } \\
\cline { 3 - 8 } & & Million UAH & $\mathbf{\%}$ & Million UAH & \% & Million UAH & \% \\
\hline 2015 & 716728 & 265448 & 37.0 & 410895 & 57.3 & 40385 & 5.7 \\
\hline 2017 & 898844 & 343758 & 38.3 & 495313 & 55.1 & 59733 & 6.6 \\
\hline 2019 & 1071666 & 433731 & 40.5 & 576126 & 53.8 & 61809 & 5.7 \\
\hline $2020^{*}$ & 1122005 & 453615 & 40.4 & 601351 & 53.6 & 67039 & 6.0 \\
\hline
\end{tabular}

* As of March 01, 2020

Source: compiled on the basis of the data from the National Bank of Ukraine [14]

Table 2

Residents' deposits attracted by deposit-taking corporations, in terms of types of currencies

\begin{tabular}{|c|c|c|c|c|c|}
\hline \multirow{2}{*}{ Period } & \multirow{2}{*}{ Total } & \multicolumn{2}{|c|}{ In national currency } & \multicolumn{2}{|c|}{ In foreign currency } \\
\cline { 3 - 6 } & & Million UAH & $\mathbf{\%}$ & Million UAH & \% \\
\hline 2015 & 716728 & 391911 & $\underline{54.7}$ & 324817 & $\underline{45.3}$ \\
\hline 2017 & 898844 & 490971 & $\underline{54.6}$ & 407872 & $\underline{45.4}$ \\
\hline 2019 & 1071666 & 642711 & $\underline{60.0}$ & 428955 & $\underline{40.0}$ \\
\hline $2020^{*}$ & 1122005 & 672356 & $\underline{60.0}$ & 449649 & $\underline{40.0}$ \\
\hline
\end{tabular}

* As of March 1, 2020

Source: compiled on the basis of the National Bank of Ukraine data [14]

Deposits of the household sector are one of the main sources of increasing deposits of residents in 2015-2019, which indicates to constant confidence of the population in the banking system of Ukraine. According to the results of 2019, the increase in balances on household accounts amounted to 45.876 million UAH, or $33.1 \%$, of the total increase in residents' deposits. In annual calculation the growth rates of household deposits amounted to $1.6 \%$ and as of January 1, 2020 they amounted to 576.126 million UAH (see Table 1). During 2015-2019, deposits of non-financial corporations increased by 168.283 million $\mathrm{UAH}$, or $63.4 \%$, from 265.448 million UAH in 2015 to 433,731 million UAH in 2019.

According to the data in Table 1, we can assert about restoration of some financial stability and confidence in the banking system by all sectors of the economy after the crisis of 2014-2017. As beginning from 2015, the growth rate of deposits in all sectors is obvious, besides that the structure of investments itself remains practically unchanged, in particular as of January 1, 2020, the share of deposits of the household sector comprised $53.8 \%$ of residents' deposits attracted by deposit-taking corporations, $40.5 \%$ of nonfinancial corporations and $5.7 \%$ of other residents.

2019 was a successful year for the banking sector - several historical records were updated. In 2019, the profit of the Ukrainian banking system exceeded the previous year's historical record by 2.7 times, from 22.3 billion UAH up to 59.6 billion UAH. Return on capital in the banking sector reached 34 per cent. This became possible both due to the rapid growth of operating income and the lowest in the decade deduction to reserves for active operations of banking institutions. In 2019, due to the slowdown of inflation, the cycle of reduction of the interest rate of the National Bank of Ukraine (NBU) began. All this is due to low inflation and macro-financial stability. In such favorable condi- tions, banks will not have problems with creating a stock of capital necessary for meeting the increased requirements in the future [11, p. 1].

Let us consider the dynamics of deposits of residents in terms of types of currencies (Table 2).

In 2016, the share of residents' deposits in the national currency decreased from $54.7 \%$ to $53.7 \%$, and the share of residents' deposits in foreign currency increased from $45.3 \%$ to $46.3 \%$. In 2016-2019, a tendency for increasing of UAH deposits of residents has been observed. From the data given in Table 2, we can conclude that the distribution of residents' deposits by currency is not equally proportional, with a large advantage of deposits in the national currency.

From the standpoint of stability of the resource base and the bank's activities in general, it is necessary to note that the largest share of its resources has been time deposits. Thus, among time deposits during 2019, the highest growth rates were observed on current accounts on demand (by 134.074 million UAH, or by $29.4 \%$, in 2019 , compared to 37.341 million UAH, or by $8.9 \%$ in 2018). In 2018-2019, the growth rate of deposits from 1 to 2 years had a downward trend. According to the results of 2018, deposits from 1 to 2 years decreased by 25.914 million UAH, or by $17.1 \%$, and according to the results of 2019 , decreased by 17.429 million UAH, or by 13.9 per cent. Such a tendency does not help in improving the structure of time deposits. In particular, the share of demand deposits exceeds $50 \%$ of residents' deposits attracted by deposittaking corporations (see Table 3 ).

The total amount of money on deposits of individuals in banks is growing. As of 2019, the citizens of the country deposited in banks UAH 57.6126 million, or 8.7 per cent more than in 2018. Strengthening of the hryvnia and attractive interest rates have led to such an increase [6]. 
Deposits of residents attracted by deposit-taking corporations, in terms of redemption terms

\begin{tabular}{|c|c|c|c|c|c|c|c|c|c|}
\hline \multirow{2}{*}{ Period } & \multirow{2}{*}{ Total } & \multicolumn{2}{|c|}{ on demand } & \multicolumn{2}{c|}{ up to 1 year } & \multicolumn{2}{c|}{ from 1 to 2 years } & \multicolumn{2}{c|}{ more than 2 years } \\
\cline { 3 - 10 } & & $\begin{array}{c}\text { Million } \\
\text { UAH }\end{array}$ & $\mathbf{\%}$ & $\begin{array}{c}\text { Million } \\
\text { UAH }\end{array}$ & $\mathbf{\%}$ & $\begin{array}{c}\text { Million } \\
\text { UAH }\end{array}$ & \% & $\begin{array}{c}\text { Million } \\
\text { UAH }\end{array}$ & \multirow{2}{*}{$\%$} \\
\hline 2015 & 716728 & 305383 & 42.6 & 271454 & 37.9 & 120055 & 16.8 & 19836 & 2.7 \\
\hline 2017 & 898844 & 419126 & 46.6 & 293337 & 32.6 & 151485 & 16.9 & 34896 & 3.9 \\
\hline 2019 & 1071666 & 590541 & 55.1 & 348542 & 32.5 & 108142 & 10.1 & 24442 & 2.3 \\
\hline $2020^{*}$ & 1122005 & 614250 & 54.8 & 369201 & 32.9 & 115063 & 10.2 & 23491 & 2.1 \\
\hline
\end{tabular}

* As of March 1, 2020

Source: compiled on the basis of the National Bank of Ukraine data [14]

Table 4

Household deposits attracted by deposit-taking corporations, in terms of types of currencies

\begin{tabular}{|c|c|c|c|c|c|}
\hline \multirow{2}{*}{ Period } & \multirow{2}{*}{ Total } & \multicolumn{2}{|c|}{ In national currency } & \multicolumn{2}{|c|}{ In foreign currency } \\
\cline { 3 - 6 } & & Million UAH & $\mathbf{\%}$ & Million UAH & \% \\
\hline 2015 & 410895 & 198876 & $\underline{48.4}$ & 212019 & $\underline{51.6}$ \\
\hline 2017 & 495313 & 252439 & $\underline{51.0}$ & 242874 & $\underline{49.0}$ \\
\hline 2019 & 576126 & 339168 & $\underline{58.9}$ & 236958 & $\underline{41.1}$ \\
\hline $2020^{*}$ & 601351 & 351949 & $\underline{58.5}$ & 249401 & $\underline{41.5}$ \\
\hline
\end{tabular}

* As of March 1, 2020

Source: compiled on the basis of data of the National Bank of Ukraine [14]

Table 5

Household deposits attracted by deposit-taking corporations, in terms of redemption terms

\begin{tabular}{|c|c|c|c|c|c|c|c|c|c|}
\hline \multirow[b]{2}{*}{ Period } & \multirow[b]{2}{*}{ Total } & \multicolumn{2}{|c|}{ on demand } & \multicolumn{2}{|c|}{ up to 1 year } & \multicolumn{2}{|c|}{ from 1 to 2 years } & \multicolumn{2}{|c|}{ more than 2 years } \\
\hline & & $\begin{array}{c}\text { Million } \\
\text { UAH }\end{array}$ & $\%$ & $\begin{array}{c}\text { Million } \\
\text { UAH }\end{array}$ & $\%$ & $\begin{array}{c}\text { Million } \\
\text { UAH }\end{array}$ & $\%$ & $\begin{array}{c}\text { Million } \\
\text { UAH }\end{array}$ & $\%$ \\
\hline 2015 & 410895 & 112524 & 27.4 & 176408 & 42.9 & 106162 & 25.8 & 15801 & 3.9 \\
\hline 2017 & 495313 & 165978 & 33.5 & 181092 & 36.6 & 142017 & 28.7 & 6227 & 1.2 \\
\hline 2019 & 576126 & 240125 & 41.7 & 237690 & 41.2 & 92669 & 16.1 & 5642 & 1.0 \\
\hline $2020^{*}$ & 601351 & 250379 & 41.6 & 249141 & 41.4 & 96175 & 16.0 & 5655 & 1.0 \\
\hline
\end{tabular}

* As of March 01, 2020

Source: compiled on the basis of data of the National Bank of Ukraine [14]

In general, in 2019, deposits of individuals in the national currency increased by 49.752 million UAH, or by $17.2 \%$, to 339.168 million UAH, in foreign currency decreased by 3.875 million UAH, or by $1.6 \%$ (Table 4 ).

At the end of 2019, hryvnia deposits of the population increased in all groups of banks. This trend was explained by the weakening of devaluation expectations and symbolic rates on foreign currency deposits. Foreign currency deposits of the population in dollar equivalent increased by $15.4 \%$ in 2019 [11, p. 2-3].

It is worth noting that until 2017, households increased their savings in both national and foreign currencies, with a certain advantage of deposits in the national currency. In 2015-2016, the share of household deposits in foreign currency was $51.6 \%$ and $52.9 \%$ respectively, and the share of household deposits in national currency was $48.4 \%$ and $47.1 \%$ respectively (see Table 4 ).

The population keeps most of its money on demand accounts or in short-term deposits (Table 5) [6].

In 2019, household deposits attracted by deposittaking corporations amounted to 576.126 million UAH. From them, short-term deposits accounted for $82.9 \%$, in particular, demand deposits amounted to $41.7 \%$, and deposits up to 1 year amounted $41.2 \%$. It should be noted that in 2015-2019 the share of demand deposits in the total amount of household deposits attracted by deposittaking corporations is constantly growing, from $27.4 \%$ in 2015 to $41.7 \%$ in 2019 , and long-term deposits from 1 up to 2 years decreases, from $25.8 \%$ in 2013 to $16.0 \%$ in 2019 (see Table 5).

During 2019, the balances on the accounts of nonfinancial corporations in foreign currency increased the most by 45.476 million UAH, or by $37.9 \%$. Although deposits in the national currency on the accounts of nonfinancial corporations increased by 45.752 million UAH, or by $20.6 \%$ but their specific weight decreased from $64.9 \%$ in 2018 to $61.8 \%$ in 2019 (Table 6). Such dynamics was formed as a result of fluctuations in earnings and payments under foreign trade agreements, as well as obtaining and servicing loans.

In 2019, deposits of non-financial corporations attracted by deposit-taking corporations increased by 92.228 million UAH or by $26.6 \%$ and amounted to 433.731 million UAH. At the same time, the increase in funds of economic entities 
Table 6

Deposits of non-financial corporations attracted by deposit-taking corporations, in terms of types of currencies

\begin{tabular}{|c|c|c|c|c|c|}
\hline \multirow{2}{*}{ Period } & \multirow{2}{*}{ Total } & \multicolumn{2}{|c|}{ In national currency } & \multicolumn{2}{|c|}{ In foreign currency } \\
\cline { 3 - 6 } & & Million UAH & $\mathbf{\%}$ & Million UAH & \% \\
\hline 2015 & 265448 & 169080 & $\underline{63.7}$ & $\underline{96368}$ & $\underline{36.3}$ \\
\hline 2017 & 343758 & 211173 & $\underline{61.4}$ & $\underline{132585}$ & $\underline{38.6}$ \\
\hline 2019 & 433731 & 268172 & $\underline{61.8}$ & $\underline{165559}$ & $\underline{38.2}$ \\
\hline $2020^{*}$ & 453615 & 270261 & $\underline{59.6}$ & $\underline{183354}$ & $\underline{40.4}$ \\
\hline
\end{tabular}

* As of March 1, 2020

Source: compiled on the basis of the National Bank of Ukraine data [14]

Table 7

Deposits of non-financial corporations attracted by deposit-taking corporations, in terms of redemption

\begin{tabular}{|c|c|c|c|c|c|c|c|c|c|}
\hline \multirow[b]{2}{*}{ Period } & \multirow[b]{2}{*}{ Total Усього } & \multicolumn{2}{|c|}{ on demand } & \multicolumn{2}{|c|}{ up to 1 year } & \multicolumn{2}{|c|}{ from 1 to 2 years } & \multicolumn{2}{|c|}{ more than 2 years } \\
\hline & & $\begin{array}{c}\text { Million } \\
\text { UAH }\end{array}$ & $\%$ & $\begin{array}{c}\text { Million } \\
\text { UAH }\end{array}$ & $\%$ & $\begin{array}{c}\text { Million } \\
\text { UAH }\end{array}$ & $\%$ & $\begin{array}{c}\text { Million } \\
\text { UAH }\end{array}$ & $\%$ \\
\hline 2015 & 265448 & 175853 & 66.2 & 76304 & 28.8 & 11058 & 4.2 & 2233 & 0.8 \\
\hline 2017 & 343758 & 214352 & 62.4 & 94388 & 27.5 & 7011 & 2.0 & 28007 & 8.1 \\
\hline 2019 & 433731 & 313147 & 72.2 & 90262 & 20.8 & 12225 & 2.8 & 18097 & 4.2 \\
\hline $2020^{*}$ & 453615 & 331214 & 73.0 & 90055 & 19.8 & 15245 & 3.4 & 17102 & 3.8 \\
\hline
\end{tabular}

* For March 1, 2020

Source: compiled on the basis of data of the National Bank of Ukraine [14]

Table 8

Interest rates of deposit-taking corporations on household deposits, in terms of types of currencies

\begin{tabular}{|c|c|c|c|c|c|c|c|}
\hline Period & Total & on demand & $\begin{array}{c}\text { up to } \\
\text { 1 year }\end{array}$ & $\begin{array}{c}\text { from 1 to } \\
\text { 2 years }\end{array}$ & $\begin{array}{c}\text { more than } \\
\text { 2 years }\end{array}$ & in national currency & $\begin{array}{c}\text { in foreign } \\
\text { currency }\end{array}$ \\
\hline 2015 & 2.2 & 4.3 & 13.7 & 14.7 & 11.1 & 17.7 & 7.5 \\
\hline 2017 & 7.8 & 3.7 & 8.9 & 9.8 & 9.0 & 12.1 & 3.4 \\
\hline 2019 & 8.3 & 3.5 & 9.8 & 9.0 & 6.8 & 12.6 & 2.6 \\
\hline $2020^{*}$ & 8.5 & 6.4 & 9.0 & 7.3 & 5.0 & 12.4 & 2.1 \\
\hline
\end{tabular}

* As of March 1, 2020

Source: compiled on the basis of the National Bank of Ukraine data [14]

took place solely due to the increase in balances of funds on current accounts, while the amounts of term funds show a steady decrease. It should be noted that in 2017-2019 the share of demand deposits in the total amount of deposits of non-financial corporations attracted by deposit-taking corporations is constantly growing from $62.4 \%$ in 2017 to $62.7 \%$ in 2018 and up to $72.2 \%$ in 2019 (Table 7).

During 2019, time deposits of non-financial corporations attracted by deposit-taking corporations decreased compared to demand deposits. Thus, in 2019, the balances on the accounts of non-financial corporations up to 1 year decreased by 3.268 million UAH, or by $3.5 \%$, deposits from 1 to 2 years decreased by 812 million UAH, or by $6.2 \%$, and deposits with a term of more than 2 years decreased by 3.263 million UAH or by $15.3 \%$ (see Table 7 ).

The price of deposits of the household sector increased during 2019 on average by $1.3 \%$, from $7.0 \%$ in 2018 to $8.3 \%$ in 2019 due to the rise in price of deposits in the national currency by $1.5 \%$, from $11.1 \%$ to $12.6 \%$ in 2019 (Table 8).

Interest rates on demand deposits of households increased by $0.9 \%$, from $2.6 \%$ in 2018 to $3.5 \%$ in 2019 , on deposits up to 1 year - by $1.1 \%$, from $8.7 \%$ to $9.8 \%$ and on deposits from 1 to 2 years - by $0.6 \%$, from $8.4 \%$ to $9.0 \%$.

Profitability on household bank deposits has declined sharply over the past five years, from $12.2 \%$ in 2015 to $7.0 \%$ in 2018. Although, according to the assessment of the domestic experts, a significant potential of monetary resources is "in the hands" of the population, which comprise a large part of money turnover and it can be placed in banking institutions of Ukraine [13, p. 174]. In the modern deposit market of households, there is a rapid decline in interest rates on foreign currency deposits. In 2015 , interest rates on household deposits in foreign currency amounted $7.5 \%$, in $2016-5.4$ per ce $\%$ nt, in $2017-$ $3.4 \%$, and in 2018-2019 $-2.5 \%$ and $2.6 \%$, respectively (see Table 8).

Conclusions from the conducted study. Thus, in the development of the deposit market of Ukraine during 2015-2019, the following can be traced: firstly, quantitative and qualitative tendencies that reflect certain aspects of banks' deposit operations: today, banks act not only as financial intermediaries in the money market, but also as tools for stimulation of the country's economy development. By accumulating free cash, financial institutions 
redistribute it among economic entities, thus participating in the process of GDP production. Therefore, the need for attracting sufficient resources for the activities of banks arise. Secondly, the results of the conducted study show a positive dynamics. During 2015-2019, the banking market demonstrates confident and balanced tactics for achieving greater and greater values of deposits, as evidenced by lower deposit rates and an increase in the amount of deposits in the national currency. Third, demand deposits with a maturity of up to one year remain the most common in Ukraine. In particular, in 2019, household funds on demand amounted $41.7 \%$, and for a period up to one year $-41.2 \%$. Further researches of effective methods of supporting the deposit market of Ukraine and the relationship between deposit and credit operations of banking institutions will allow to suggest ways for increasing the implementation of their main function concerning rational redistribution of banking resources.

\section{References:}

1. Halitseys'ka YU. M. (2013) Stan ta dominuyuchi tendentsiyi rozvytku svitovoyi bankivs'koyi systemy. [Status and dominant trends in the world banking system.] Naukovi zapysky Natsional'noho universytetu "Ostroz'ka akademiya". Ekonomika, vol. 22, pp. 23-27. Available at: http://nbuv.gov.ua/UJRN/Nznuoa_2013_22_7. (accessed 23 March 2020)

2. Hurzhyy T.O. (2018) Dynamika dzherel i struktury finansovykh resursiv domohospodarstv [Dynamics of sources and structure of financial resources of households.]. Intelekt XXI, no. 4, pp. $58-63$.

3. Dzyublyuk O. (2019) Rol' bankivs'koyi systemy v innovatsiynomu rozvytku ekonomiky [The role of the banking system in the innovative development of the economy]. Visnyk Ternopil's'koho natsional'noho ekonomichnoho universytetu, vol. 1, pp. 81-101. Available at: http://nbuv.gov.ua/UJRN/Vtneu_2019_1_9. (accessed 2 April 2020)

4. Krysovatyy A., Gospodarowicz A. (2016) Modern determinants of fiscal policy: local and international dimension. Monograph.Wroclaw, $282 \mathrm{p}$.

5. Kovalenko V.V., Serhyeyeva O.S. (2019) Zaoshchadzhennya naselennya u zabezpechenni finansovykh resursiv bankiv [Savings of the population in providing financial resources of banks.]. Infrastruktura rynku, vol. 28, pp. 275-283. Available at: http://www.market-infr.od.ua/journals/2019/28_2019_ukr/43.pdf. (accessed 28 March 2020)

6. Kredyty ta depozyty - tendentsiyi 2019 roku [Loans and deposits - trends of 2019]. URL: https://mind.ua/ news/20201267-krediti-ta-depoziti-tendenciyi-2019-roku/ (accessed 28 March 2020)

7. Kumeyko O.M., Dereza V.M. Otsinka depozytnoyi polityky PAT «BANK KREDYT DNIPRO» ta napryamy yiyi udoskonalennya [Evaluation of the deposit policy of PJSC "BANK CREDIT DNIPRO" and directions of its improvement]. Available at: http://economyandsociety.in.ua/journal-19/26-stati-19/2524-kumejko-o-m-dereza-v-m (accessed 28 March 2020)

8. Motoryna I. (2009) Dyversyfikatsiya yak sposib znyzhennya ryzyku mozhlyvykh zbytkiv vkladiv fizychnykh osib $\mathrm{v}$ umovakh finansovoyi kryzy [Diversification as a way to reduce the risk of possible losses of deposits of individuals in a financial crisis]. Visnyk Kyyivs'koho natsional'noho universytetu imeni Tarasa Shevchenka. Ekonomika, vol. 116, pp. $52-55$. Available at: http://nbuv.gov.ua/UJRN/VKNU_Ekon_2009_116_19 (accessed 3 April 2020)

9. Novikov Viktor. Nasha zadacha - reshit' problemu s bankami-zombi [Our task is to solve the problem with zombie banks]. Available at: https://finclub.net/analytics/viktor-novikov-nasha-zadacha-reshit-problemu-s-bankami-zombi.html (accessed 23 March 2020)

10. Nosova Ye. A. Zaoshchadzhennya domohospodarstv yak dzherelo investytsiynykh resursiv v Ukrayini [Household savings as a source of investment resources in Ukraine.]. Visnyk Kyyivs'koho natsional'noho universytetu im. Tarasa Shevchenka, vol. 167, pp. 73-81. Available at: http://bulletin-econom.univ.kiev.ua/archives/1039 (accessed 2 April 2020)

11. Stockmarket. Rehulyarna informatsiya za 4 kvartal 2019 roku. AT «OKSI BANK» [Stockmarket. Regular information for the 4th quarter of 2019. JSC “OXY BANK"]. Available at: https://stockmarket.gov.ua/cabinet/xml/show/manrep/33572 (accessed 28 March 2020)

12. Pavlyuk T.I., Urbanovych V.A. Analiz dynamiky ta struktury zaoshchadzhen' naselennya Ukrayiny [Analysis of the dynamics and structure of savings of the population of Ukraine]. Available at: https://naukajournal.org/index.php/ naukajournal/article/view/948 (accessed 1 April 2020)

13. Rosola U. V. (2018) Otsinka suchasnoho stanu depozytnoho rynku Ukrayiny [Assessment of the current state of the deposit market of Ukraine]. Naukovyy visnyk Mukachivs'koho derzhavnoho universytetu. Seriya Ekonomika, vol. 1, pp. 174-180. Available at: http://nbuv.gov.ua/UJRN/nvmdue_2018_1_28. (accessed 23 March 2020)

14. Sayt Natsional'noho banku Ukrayiny [Website of the National Bank of Ukraine]. Available at: https://bank.gov.ua/ (accessed 23.03.2020)

15. Chaykovs'kyy YA. I., Chaykovs'ka I.YA. (2016) Udoskonalennya upravlinnya resursamy bankiv Ukrayiny z vrakhuvannyam yevropeys'koho dosvidu [Improving the management of resources of Ukrainian banks taking into account the European experience]. Nauka moloda. Zb. nauk. prats' molodykh vchenykh TNEU. Ternopil'.TNEU, no. 24, pp. 130-140.

\section{Список літератури:}

1. Галіцейська Ю. М. Стан та домінуючі тенденції розвитку світової банківської системи. Наукові записки Національного університету “Острозька академія”. Економіка. 2013. Вип. 22. С. 23 - 27. URL: http://nbuv.gov.ua/UJRN/ Nznuoa_2013_22_7 (дата звернення:23.03.2020) 
2. Гуржий Т.О. Динаміка джерел і структури фінансових ресурсів домогосподарств. Інтелект XXI. 2018. Вип. № 4. С. $58-63$.

3. Дзюблюк О. Роль банківської системи в інноваційному розвитку економіки. Вісник Тернопільського наиіонального економічного університету. - 2019. - Вип. 1. - С. 81 - 101. - Режим доступу:http://nbuv.gov.ua/UJRN/ Vtneu_2019_1_9 (дата звернення: 02.04.2020)

4. Krysovatyy A., Gospodarowicz A. Modern determinants of fiscal policy: local and international dimension. Monograph. Wroclaw. 2016. 282 p.

5. Коваленко В.В., Сергєєва О.С. Заощадження населення у забезпеченні фінансових ресурсів банків. Інфраструктура ринку. Випуск 28. 2019. С. 275 - 283. URL: http://www.market-infr.od.ua/journals/2019/28_2019_ukr/43.pdf (дата звернення: 28.03.2020)

6. Кредити та депозити - тенденції 2019 року. URL: https://mind.ua/news/20201267-krediti-ta-depoziti-tendenciyi2019-roku (дата звернення: 28.03.2020)

7. Кумейко О.М., Дереза В.М. Оцінка депозитної політики ПАТ «БАНК КРЕДИТ ДНІПРО» та напрями їі удосконалення. URL: http://economyandsociety.in.ua/journal-19/26-stati-19/2524-kumejko-o-m-dereza-v-m (дата звернення: 28.03.2020)

8. Моторина I. Диверсифікація як спосіб зниження ризику можливих збитків вкладів фізичних осіб в умовах фінансової кризи. Вісник Київського наџіонального університету імені Тараса Шевченка. Економіка. 2009. Вип. 116. С. 52-55. URL: http://nbuv.gov.ua/UJRN/VKNU_Ekon_2009_116_19. (дата звернення: 03.04.2020)

9. Новиков Виктор. Наша задача - решить проблему с банками-зомби. URL: https://finclub.net/analytics/viktornovikov-nasha-zadacha-reshit-problemu-s-bankami-zombi.html (дата звернення: 23.03.2020)

10. Носова Є.А. Заощадження домогосподарств як джерело інвестиційних ресурсів в Україні. Вісник Київського національного університету ім. Тараса Шевченка. 2015. Вип. 167. C. 73-81. URL: http://bulletin-econom.univ.kiev.ua/ archives/1039 (дата звернення: 02.04.2020)

11. Stockmarket. Регулярна інформація за 4 квартал 2019 року. АТ «ОКСІ БАНК». URL: https://stockmarket.gov.ua/ cabinet/xml/show/manrep/33572 (дата зверненння: 28.03.2020)

12. Павлюк T.I., Урбанович B.А. Аналіз динаміки та структури заощаджень населення України. URL: https://naukajournal.org/index.php/naukajournal/article/view/948 (дата звернення: 01.04.2020)

13. Росола У. В. Оцінка сучасного стану депозитного ринку України. Науковий вісник Мукачівського державного університету. Серія Економіка. 2018. Вип. 1. С. 174 - 180. URL:http://nbuv.gov.ua/UJRN/nvmdue_2018_1_28. (дата звернення: 28.03.2020)

14. Сайт Національного банку України. URL: https://bank.gov.ua/ (дата звернення: 23.03.2020)

15. Чайковський Я. І., Чайковська I.Я. Удосконалення управління ресурсами банків України з врахуванням європейського досвіду. Наука молода. Зб. наук. праць молодих вчених ТНЕУ. Тернопіль.ТНЕУ. 2016. № 24. С. 130-140.

\section{ЗАОЩАДЖЕННЯ В БАНКІВСЬКИХ УСТАНОВАХ УКРАЇНИ ЯК ЧИННИК ПІДВИЩЕННЯ ЕФЕКТИВНОСТІ ФОРМУВАННЯ ТРУДОВОГО ПОТЕНЦАЛУ НАСЕЛЕННЯ}

В статті висвітлена проблематика теоретико-емпіричного наукового дослідженнязаощаджень в банківських установах і наповнення новим змістом їх залучення для підвищення ефективності трудового потенціалу населення в умовах формування розвиненої банківської системи. Теоретичну й методологічну основу дослідження склали діалектичний, системно-логічний і комплексний методи наукового пізнання, які дозволили забезпечити вірогідність і обгрунтованість висновків і рекомендацій. Прикладна значимість дослідження полягає в тому, що діагностовано динаміку і структуру депозитів резидентів, які залучені депозитними корпораиіями, за секторами економіки і розрізі валют; проведено аналіз сучасного стану вкладних операџій банківських установ України; визначено особливості формування заощаджень населення. Аргументовано відновлення певної фінансової стабільності та довіри до банківської системи з боку усіх секторів економіки після кризових 2014-2017 рр. Визначено, що рентабельність капіталу у банківському секторі сягнула 34 \%, що стало можливим як завдяки стрімкому зростанню операчійних доходів, так і найнижчим за десятиліття відрахуванням до резервів під активні операції банківських установ. Систематизовано основні науково-методичні підходи до обтрунтування: стану розподілу вкладів резидентів за валютами і великою перевагою депозитів у національній валюті; доцільності залучення строкових вкладів для стабільності ресурсної бази і загалом діяльності банку; тендениії найбільшого тримання грошей населенням на рахунках «до запитання» або на короткострокових депозитах; нарощення коштів суб'єктів господарської діяльності виключно за рахунок збільшення залишків коштів на поточних рахунках. Послідовність діагностування кількісних та якісних тенденцій, котрі відображають окремі сторони депозитних операчій банків, свідчить про сучасний тренд: банки виступають не тільки, як фінансові посередники на грошовому ринку, але і як інструменти стимулювання розвитку економіки країни. Тому раиіональному перерозподілу банківських ресурсів сприятимуть подальші дослідження ефективних методів підтримки депозитного ринку України.

Ключові слова: банківські установи; банківські ресурси; депозити резидентів; депозити домашніх господарств; депозити нефінансових корпораиій; депозитні відсотки. 


\section{СБЕРЕЖЕНИЯ В БАНКОВСКИХ УЧРЕЖДЕНИЯХ УКРАИНЫ КАК ФАКТОР ПОВЫШЕНИЯ ЭФФЕКТИВНОСТИ ФОРМИРОВАНИЯ ТРУДОВОГО ПОТЕНЦИАЛА НАСЕЛЕНИЯ}

Проведен анализ динамики и структуры депозитов юридических лич и вкладов физических лии за период 2015-2019 годов в банковской системе Украинь в разрезе видов валют и сроков погашения. Представлена динамика изменения прочентных ставок по депозитам резидентов, вовлеченных депозитными корпорациями в 2015-2019 г2. на счета нефинансовых корпорачий и домашних хозяйств. Обоснованы мероприятия по развитию и совершенствованию депозитных операций. Практическое значение полученных результатов заключается 8 научном обосновании путей дальнейшего развития депозитных операций банков по формированию банковских ресурсов, составляет вклад в современные подходы к обеспечению ресурсами и функиионирования банковской системы Украины.

Ключевые слова: банковские учреждения; банковские ресурсы; депозиты резидентов; депозиты домашних хозяйств; депозиты нефинансовых корпораций; депозитные проиентыл.

DOI: https://doi.org/10.32838/2523-4803/70-3-53

УДК 336.5:63(477-22)

\section{Шинкарук Л.В.}

доктор економічних наук, професор, член-кореспондент НАН України,

завідувач кафедри виробничого та інвестиційного менеджменту

Національний університет

біоресурсів і природокористування України

\section{Титарчук I.M.}

кандидат економічних наук,

доцент кафедри виробничого та інвестиційного менеджменту

Національний університет

біоресурсів і природокористування України

Shynkaruk Lidiia, Tytarchuk Iryna

National University of Life and Environmental Sciences of Ukraine

\section{ДЕРЖАВНІ ВИТРАТИ У СФЕРІ СІЛЬСЬКОГО ГОСПОДАРСТВА ТА РОЗВИТКУ СІЛЬСЬКИХ ТЕРИТОРІЙ}

\footnotetext{
У статті розглянуто систему державних витрат на сільськогосподарську діяльність та розвиток сільських територій у розрізі державного та місиевого бюджетів відповідно до економічної структури видатків та за підсекторами аграрної сфери тощзо. Встановлено, щзо важливою умовою розвитку сільських територій та забезпечення ефективності ведення сільськогосподарської діяльності є ефективна державна підтримка. На підставі здійснених досліджень сформовано висновки та надано пропозииії щзодо коригування механізму фінансування аграрної сфери. Проаналізовано низку законодавчих та стратегічних документів, якими передбачаються види державної підтримки та реформування аграрної сфери; відзначено, що відсутність узгодженого переліку стратегічних иілей, їх середньострокова невпорядкованість та значна кількість створюють несприятливі умови для ефективного бюджетного планування державних витрат на сільське господарство та розвиток сільських територій.

Ключові слова: державні витрати, державний бюджет, сільське господарство, сільські території, державна підтримка, аграрний сектор.
}

Постановка проблеми. Нині Україна перебуває на складному етапі розвитку економіки або навіть на порозі соціально-економічної кризи, яка охопила всі країни світу через пандемію COVID-19 та ускладнила умови функціонування усіх секторів економіки. Аграрний сек- тор останніми роками був флагманом зростання та врожайності й надходжень від експорту, а також частки у ВВП країни, тому його державній підтримці відводиться особлива роль. Механізм державного фінансування сільського господарства та розвитку сільських території, 